\title{
Penguatan Kompetensi Pengelola Perpustakaan Madrasah dan Sekolah Melalui Diklat Berkesinambungan
}

\author{
Inda Fitri \\ UIN Imam Bonjol Padang \\ E-Mail: indacaniago@uinib.ac.id \\ Mega Orina Fitri \\ UIN Imam Bonjol Padang \\ E-Mail: megaorinafitri@uinib.ac.id \\ Zulvia Trinova \\ UIN Imam Bonjol Padang \\ E-Mail: zulviatrinova@uinib.ac.id
}

Received: 23-09-2021

Revised: 16-10-2021

Accepted: 8-11-2021

DOI: $10.24036 /$ ib.v3i1.276

\begin{abstract}
Education and training for madrasah and school library managers in the city of Padang to manage existing libraries should have an educational background in Library Science. In fact, the head of the library is a teacher in the field of study and the library manager is still honorary. Lack of attention from the leadership so that library managers are not creative because there is no continuous education and training. The questionnaire was distributed by the service team to 74 schools and madrasahs in the city of Padang and only 30 returned questionnaires, where the average school library accreditation score was very low and below the standard value of accreditation issued by the Jakarta National Library. This research-based service method is Participation Action Research (PAR) which involves parties from the Head of the West Sumatra Provincial Education Office, West Sumatra Provincial Archives and Libraries, the Head of the Ministry of Religion of Padang City is invited as a speaker. From the results of the education and training activities, it is not clear that the policies that will be carried out by leaders and decision makers to advance the library in a better direction.
\end{abstract}

Keywords: Library Human Resources, Competence, library training

\section{Abstrak}

Pendidikan dan pelatihan bagi pengelola perpustakaan madrasah dan sekolah se-Kota Padang untuk mengelola perpustakaan yang ada mestinya memiliki latar belakang pendidikan Ilmu Perpustakaan. Faktanya, kepala perpustakaan adalah guru bidang studi dan pengelola perpustakaan masih berstatus honorer. Kurangnya perhatian dari pimpinan sehingga pengelola perpustakaan tidak kreatif karena tidak adanya pendidikan dan pelatihan yang berkesinambungan. Angket disebar tim pengabdian ke 74 sekolah dan madrasah di Kota Padang dan angket yang kembali hanya 30 yang rata-rata nilai akreditasi perpustakaan sekolah sangat rendah dan di bawah standar nilai akreditasi yang dikeluarkan oleh Perpustakaan Nasional Jakarta. Metode pengabdian berbasis riset ini adalah Participation Action Research (PAR) yang melibatkan pihak dari Kepala Dinas Pendidikan Propinsi Sumatera Barat, Kearsipan dan Perpustakaan Propinsi Sumatera Barat, Kepala Kementrian Agama Kota Padang diundang sebagai pemateri. Dari hasil kegiatan diklat belum terlihat nyata kebijakan yang akan dilakukan oleh para pemimpin dan pengambil keputusan untuk memajukan perpustakaan ke arah yang lebih baik. 
Published by Program Studi Perpustakaan dan IImu Informasi

FBS Universitas Negeri Padang, Indonesia

Kata kunci: Pengelolaan Perpustakaan, Kompetensi, diklat perpustakaan

\section{PENDAHULUAN}

Tenaga pustaka/pustakawan merupakan sumber daya manusia yang perlu diperhatikan, sumber daya manusia adalah unsur penting dalam sebuah organisasi (Azmar, 2018; Sumbangsih \& Nelisa, 2013). Unsur ini tentunya mempunyai peranan yang sangat menentukan bagi keberhasilan dari pelaksanaan berbagai kegiatan yang diselenggarakan oleh organisasi bersangkutan. Karena itu berbagai upaya pembinaan dan pengembangan sumber daya manusia perlu dilakukan secara sistematis dan berkesinambungan (Kristiawan, 2016; Purnomo, 2004).

Sumber daya manusia yang ditugaskan untuk mengelola perpustakaan di banyak lembaga pendidikan, khususnya di perpustakaan sekolah/madrasah, umumnya hampir tidak pernah mendapatkan perhatian serius. Bahkan banyak ditangani oleh mereka yang sama sekali tidak mempunyai latar belakang pendidikan dan keterampilan yang memadai dalam masalah pengelolaan perpustakaan (Purnomo, 2004; RE, 2003; Sudarsono, 2017; ). Pengelola perpustakaan juga tidak memahami tugas pokok dan bagaimana cara bersikap yang menyenangkan terhadap pemustaka. Banyak yang sehari-hari malah mengerjakan tugas sebagai tata usaha, administrasi dan lain-lainnya (Adhiarya et al., 2013; Djafar et al., 2018; Santoso, 2007).
Berdasarkan pengabdian sebelumnya yang pernah dilakukan oleh Desriyeni dan kawan-kawan di perpustakaan SMAN 1 Bukit Sundi dan SMAN 1 Lembang Jaya Kabupaten Solok, mereka telah menemukan masalah bahwa dalam pengembangan perpustakaan sekolah belum adanya SDM yang mengelola perpustakaan tersebut karena hanya dikelola oleh guru yang mengajar juga, sehingga tidak mencapai tujuan yang diharapkan sebagaimana seharusnya fungsi dan tujuan dari perpustakaan sekolah itu sendiri. (Desriyeni, 2018).

Kurangnya perhatian dari pimpinan sekolah menjadikan para pengelola perpustakaan menjadi tidak kreatif dan tidak adanya pendidikan dan pelatihan yang berkesinambungan yang bisa meningkatkan kreatifitas dan keahlian mereka dalam mengelola perpustakaan. Selama ini semenjak berdirinya Jurusan Prodi Ilmu Perpustakaan Fakultas Adab dan Humaniora UIN Imam Bonjol Padang di bulan Juni 1999, hingga sekarang sudah mencetak banyak alumni yang sudah bekerja di beberapa perpustakaan di seluruh lembaga di Sumatera Barat baik itu di Lembaga Sekolah, Perguruan Tinggi maupun lembaga instansi lainnya, dari sekian alumni yang bekerja rata-rata mereka masih berstatus pegawai honorer dan kurang mendapatkan perhatian dari pimpinan tempat mereka bekerja, selain itu, pembinaan dan pelatihan juga sangat jarang atau boleh dikatakan hanya segelintir dari mereka yang merasakan 
pernah melakukan pelatihan atau seminar yang bisa menambah wawasan mereka dalam mengelola perpustakaan. Rata-rata mereka hanya mendapatkan pelatihan/diklat/seminar

kepustakawanan dua tahun sekali bahkan ada yang tidak pernah sama sekali.

Sementara dalam penilaian sekolah yang semenjak tahun 2000 sudah diterapkan oleh Departemen pendidikan dan Kebudayaan dalam program yang disebut PISA (Programme for International Student Assessment) yang dirilis Organisation for Economic Co-operation and Development (OECD) sebuah organisasi untuk kerjasama ekonomi dan pembangunan melaksanakan penilaian tiga tahunan atas budaya literasi 72 negara pada tahun 2016 (Hayati, 2019; Nuswantara, 2018). Hasilnya menunjukkan dari ke tiga indeks yang di uji, yaitu indeks literasi sains, matematika dan literasi membaca, yang paling rendah nilai kenaikan poinnya adalah indeks literasi membaca yang hanya naik satu point dari 396 pada tahun 2012 menjadi 397 pada tahun 2015 (Hasanah, 2019; Irawan, 2019; Vanbela et al., 2018).

Melihat kondisi dari standar PISA tadi bisa dikatakan bahwa tingkat literasi membaca di Indonesia sangat rendah dibandingkan dengan negaranegara lain di dunia (Zati, 2018) (Rosmaya, 2018) (Suragangga, 2017). Selain itu, pada tahun 2016, Central Connecticut State University merilis hasil "The World Most Literate Nation Study" (Aguswara, 2018) (Abrori, 2018) (AUDINA, 2019). Studi ini selain menggunakan hasil penilaian PISA juga menambahkan ketersediaan dan ukuran perpustakaan serta akses terhadap informasi. Dari 61 negara yang diteliti, Indonesia berada pada posisi ke-60 di atas Botswana. Untuk kawasan ASEAN posisi Indonesia berada di bawah Singapura, Malaysia, dan Thailand (Setianda \& Andadari, 2015) (Nurhayati, 2012; Prianto, 2015). Kenyataan di lapangan adapun ukuran perpustakaan serta akses terhadap informasi bukanlah menjadi bagian yang penting dan juga bukanlah menjadi sebuah kebutuhan di setiap perpustakaan sekolah akan tetapi baru sekedar pelengkap demi memenuhi standar minimal adanya perpustakaan. (berdasarkan survey dan pengamatan penulis selama ini saat mengantar mahasiswa magang prakrek kerja lapangan di berbagai sekolah-dan madrasah di Sumatera Barat).

\section{METODE}

Metode yang dipakai dalam Pengabdian berbasis riset ini adalah Participation Action Research (PAR) yang melibatkan semua pihak antara lain Kepala Dinas Pendidikan Propinsi Sumatera Barat, Kepala Dinas Kearsipan dan Perpustakaan Propinsi Sumatera Barat, Kepala Kementrian Agama Kota Padang diundang sebagai pemateri dalam acara diklat tersebut untuk menyampaikan arah kebijakan masing-masing kepala tentang keberadaan perpustakaan sekolah dan madrasah di Kota Padang.

Metode yang Tim Pengabdian Masyarakat lakukan dalam kegiatan penguatan kompetensi pengelola perpustakaan madrasah dan sekolah 
se-kota Padang adalah dengan melaksanakan pendidikan dan pelatihan kepada peserta yang mengembalikan angket yang sudah disebar sebelumnya ke-74 sekolah negeri di Kota Padang, dari 74 sekolah yang disebar angket rencana semula akan dilaksanakan dua kali kegiatan yaitu diklat dasar dan diklat lanjutan, dimana masing-masing sekolah akan dipetakan mana sekolah yang akan mengikuti diklat tingkat dasar dan sekolah mana yang akan mengikuti diklat tingkat lanjutan.

Akan tetapi setelah dilakukan penyebaran angket dan yang kembali hanya sebanyak 30 buah angket dan rata-rata seluruh sekolah yang mengembalikan angket dibawah standar akreditasi, akhinya Tim Pengabdian Masyarakat memutuskan untuk tidak jadi memetakan/mengelompokkan sekolah dikarenakan seluruh sekolah/madrasah kondisi perpustakaannya sama saja. Semula tim pengabdian akan memetakan kondisi dari perpustakaan sekolah tersebut dan dibagi dalam dua tahap, tahap I diklat tingkat dasar bagi sekolah yang memperoleh nilai akreditasi perpustakaan B, tahap ke II diklat tingkat lanjutan bagi perpustakaan sekolah yang mempunyai nilai akreditasi A.

Akan tetapi setelah disebar angket ternyata dari 30 sekolah yang mengembalikan angket semuanya dibawah standar akreditasi, Jadi ke-30 peserta yang tim pengabdi undang menjadi peserta diklat disatukan semua dan semua peserta mengikuti diklat tingkat dasar dan diklat tingkat lanjutan yang diadakan tanggal 8 sampai 11 November 2018.

Sebelum kegiatan dilaksanakan Tim Pengabdian masyarakat juga menghubungi dan mengundang nara sumber dari;

1. Kepala Kementrian Agama Kota padang untuk bisa menjadi narasumber diacara diklat yang diadakan sekaligus meminta izin dalam pemakaian gedung aula kemenag kota Padang. Dalam hal ini langsung diwakili oleh Kepala Kementrian Agama Kota Padang, Bapak Drs. Marjanis, M.Pd.

2. Kepala Dinas Pendidikan Propinsi Sumatera Barat juga diundang untuk menjadi narasumber pada kegiatan diklat yang dalam hal ini langsung di wakili oleh kepala Dinas Pendidikan Propinsi Sumatera Barat, Bapak Drs. Buhasman, MM.

Kepala Dinas Kearsipan dan Perpustakaan Propinsi Sumatera Barat juga diundang untuk menjadi narasumber yang dalam hal ini diwakili oleh Bapak Yendri Buharma, SS., salah seorang pustakawan dari Dinas Kearsipan dan Perpustakaan Propinsi Sumatera Barat.

\section{HASIL DAN PEMBAHASAN}

Berdasarkan data sebelumnya hasil pengabdian tahun 2017 kami melihat permasalahan bahwa kondisi perpustakan sekolah/madrasah di kota Padang sungguh sangat memprihatinkan antara lain gedung dan ruang perpustakaan yang tidak kondusif, rata-rata pengelola pustaka (pustakawan) belum berstatus PNS ditambah lagi perpustakaan yang belum terkelola dengan baik terbukti dengan masih banyaknya perpustakaan yang belum ada sistem automasi di 
Published by Program Studi Perpustakaan dan Ilmu Informasi

setiap perpustakaan serta belum adanya pembinaan yang serius dilakukan oleh internal sekolah maupun dari lembaga/organisasi profesi kepustakawanan lainnya bagi pengelola-pengelola perpustakaan tersebut, serta jumlah perpustakaan dan tenaga perpustakaan sekolah/madrasah masih berada dibawah rata-rata standar perpustakaan yang ditetapkan pemerintah. Hal ini dibuktikan dari penyebaran angket yang telah Tim Pengabdi lakukan di bulan September 2018. Berdasarkan data angket yang sudah kembali dari 74 sekolah yang disebar angket yang kembali hanya 30 buah angket.

Berikut digambarkan hasil nilai angket dari 30 sekolah yang mengembalikan. 18 buah tingkat SMP/MTsN rata-rata memperoleh nilai akreditasi 30,89, nilai terendah 12,3 SMP 20 dan nilai tertinggi 50,14 SMP 11. Sementara untuk tingkat SMA/MAN dari 12 sekolah yang mengembalikan angket nilai rata-rata akreditasi yang diperoleh hanya 40,50, untuk nilai terendah 23,87 SMKN 7 dan nilai tertinggi 57,4 SMKN 9, sementara untuk bisa memperoleh nilai akreditasi $B$ saja harus memperoleh nilai sebanyak 76 dan nilai A harus memperoleh nilai 91.

\section{Grafik Nilai Akreditasi Perpustakan Sekolah Tingkat SLTA}

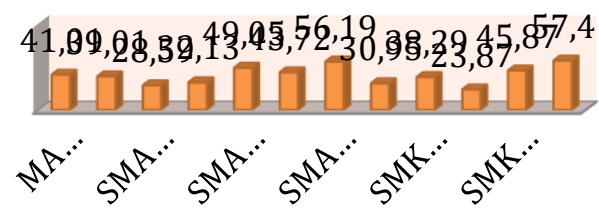

Gambar 1

Nilai Akreditasi Perpustakaan Sekolah Tingkat SLTA

\section{Grafil Nilai Akreditasi \\ Perpustakaan Sekolah Tingkat SLTP}
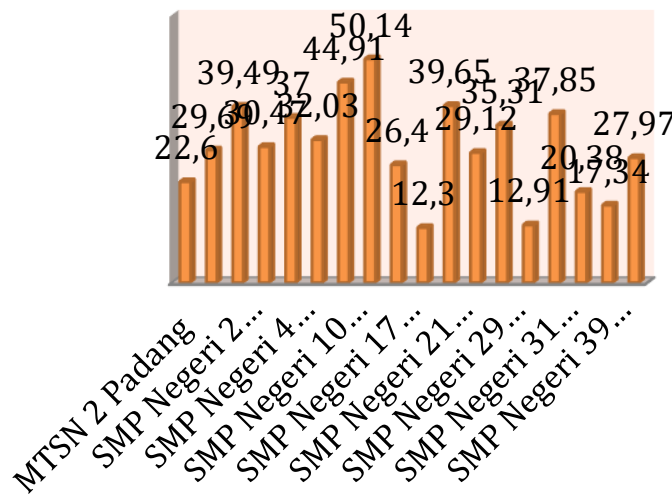

Gambar 2

Nilai Akreditasi Perpustakaan Sekolah

Tingkat SLTP

Berikut digambarkan nilai hasil keseluruhan sekolah dan madrasah tingkat SLTA dan SLTP

Tabel 1. Hasil Nilai Akreditasi

Keseluruhan Perpustakaan

Sekolah/Madrasah 
Published by Program Studi Perpustakaan dan Ilmu Informasi FBS Universitas Negeri Padang, Indonesia

\begin{tabular}{|c|c|c|c|c|c|}
\hline No & Nama Sekolah & Total Nilai & $\begin{array}{l}\text { Predikat } \\
\text { Penilaian }\end{array}$ & $\begin{array}{l}\text { Kekurangan Nilai } \\
\text { Untuk Akreditasi B }\end{array}$ & $\begin{array}{l}\text { Kekurangan Nilai } \\
\text { Untuk Akreditasi } \\
\text { A }\end{array}$ \\
\hline 1 & MAN2 & 41,01 & \begin{tabular}{|l|}
$\begin{array}{l}\text { Belum } \\
\text { terakreditasi }\end{array}$ \\
\end{tabular} & 34,99 & 49,99 \\
\hline 2 & SMA Negeri 1 & 39,01 & \begin{tabular}{|l|} 
Belum \\
terakreditasi
\end{tabular} & 36,99 & 51,99 \\
\hline 3 & SMA Negeri 3 & 28,59 & \begin{tabular}{|l} 
Belum \\
terakreditasi
\end{tabular} & 47,41 & 62,41 \\
\hline 4 & SMA Negeri 5 & 32,13 & \begin{tabular}{|l|} 
Belum \\
terakreditasi
\end{tabular} & 43,87 & 58,87 \\
\hline 5 & SMA Negeri 10 & 49,05 & \begin{tabular}{|l|} 
Belum \\
terakreditasi \\
\end{tabular} & 26,95 & 41,95 \\
\hline $\begin{array}{l}6 \\
7\end{array}$ & $\begin{array}{l}\text { SMA Negeri } 12 \\
\text { SMA Negeri } 16\end{array}$ & $\begin{array}{l}43,72 \\
56,19\end{array}$ & \begin{tabular}{|l|} 
Belum \\
terakreditasi \\
Belum \\
terakreditasi
\end{tabular} & $\begin{array}{l}32,28 \\
19,81\end{array}$ & $\begin{array}{l}47,28 \\
34,81\end{array}$ \\
\hline 8 & SMK Negeri 5 & 30,95 & \begin{tabular}{|l|} 
Belum \\
terakreditasi
\end{tabular} & 45,05 & 60,05 \\
\hline 9 & SMK Negeri 6 & 38,29 & \begin{tabular}{|l|} 
Belum \\
terakreditasi
\end{tabular} & 37,71 & 52,71 \\
\hline 10 & SMK Negeri 7 & 23,87 & $\begin{array}{l}\text { Belum } \\
\text { terakreditasi }\end{array}$ & 52,13 & 67,13 \\
\hline 11 & SMK Negeri 8 & 45,87 & \begin{tabular}{|l|} 
Belum \\
terakreditasi
\end{tabular} & 30,13 & 45,13 \\
\hline 12 & SMK Negeri 9 & 57,4 & \begin{tabular}{|l|} 
Belum \\
terakreditasi \\
\end{tabular} & 18,6 & 33,6 \\
\hline 13 & MTSN 2 & 22,6 & \begin{tabular}{|l|} 
Belum \\
terakreditasi
\end{tabular} & 53,4 & 68,4 \\
\hline 14 & MTSN 4 & 29,69 & \begin{tabular}{|l|} 
Belum \\
terakreditasi
\end{tabular} & 46,31 & 61,31 \\
\hline 15 & SMP Negeri 2 & 39,49 & \begin{tabular}{|l|} 
Belum \\
terakreditasi
\end{tabular} & 36,51 & 51,51 \\
\hline 16 & SMP Negeri 3 & 30,47 & \begin{tabular}{|l} 
Belum \\
terakreditasi
\end{tabular} & 45,53 & 60,53 \\
\hline 17 & SMP Negeri 4 & 37 & \begin{tabular}{|l|}
$\begin{array}{l}\text { Belum } \\
\text { terakreditasi }\end{array}$ \\
\end{tabular} & 39 & 54 \\
\hline 18 & SMP Negeri 7 & 32,03 & \begin{tabular}{|l|} 
Belum \\
terakreditasi
\end{tabular} & 43,97 & 58,97 \\
\hline 19 & SMP Negeri 10 & 44,91 & \begin{tabular}{|l|} 
Belum \\
terakreditasi
\end{tabular} & 31,09 & 46,09 \\
\hline 20 & SMP Negeri 11 & 50,14 & \begin{tabular}{|l|} 
Belum \\
terakreditasi
\end{tabular} & 25,86 & 40,86 \\
\hline $\begin{array}{l}21 \\
22\end{array}$ & $\begin{array}{l}\text { SMP Negeri } 17 \\
\text { SMP Negeri } 20\end{array}$ & $\begin{array}{l}26,4 \\
12,3\end{array}$ & $\begin{array}{l}\text { Belum } \\
\text { terakreditasi } \\
\text { Belum } \\
\text { terakreditasi } \\
\end{array}$ & $\begin{array}{l}49,6 \\
63,7\end{array}$ & $\begin{array}{l}64,6 \\
78,7\end{array}$ \\
\hline 23 & SMP Negeri 21 & 39,65 & \begin{tabular}{|l|} 
Belum \\
terakreditasi
\end{tabular} & 36,35 & 51,35 \\
\hline 24 & SMP Negeri 22 & 29,12 & $\begin{array}{l}\text { Belum } \\
\text { terakreditasi }\end{array}$ & 46,88 & 61,88 \\
\hline 25 & SMP Negeri 29 & 35,31 & \begin{tabular}{|l|} 
Belum \\
terakreditasi
\end{tabular} & 40,69 & 55,69 \\
\hline $\begin{array}{l}26 \\
27\end{array}$ & $\begin{array}{l}\text { SMP Negeri } 30 \\
\text { SMP Negeri } 31\end{array}$ & $\begin{array}{l}12,91 \\
37,85 \\
\end{array}$ & $\begin{array}{l}\text { Belum } \\
\text { terakreditasi } \\
\text { Belum } \\
\text { terakreditasi }\end{array}$ & $\begin{array}{l}63,09 \\
38,15 \\
\end{array}$ & $\begin{array}{l}78,09 \\
53,15 \\
\end{array}$ \\
\hline 28 & SMP Negeri 38 & 20,38 & \begin{tabular}{|l|} 
Belum \\
terakreditasi
\end{tabular} & 55,62 & 70,62 \\
\hline 29 & SMP Negeri 39 & 17,34 & \begin{tabular}{|l|} 
Belum \\
terakreditasi
\end{tabular} & 58,66 & 73,66 \\
\hline 30 & SMP Negeri 40 & 27,97 & \begin{tabular}{|l|} 
Belum \\
terakreditasi
\end{tabular} & 48,03 & 63,03 \\
\hline
\end{tabular}

Sementara yang menjadi indikator penilaian dalam angket yang disebar dirangkum dalam 6 indikator:

1. Pengembangan Koleksi terdiri 3 komponen dan 26 pertanyaan yaitu: (1) Kebijakan 2 pertanyaan, (2) Seleksi terdiri dari 3 komponen yaitu; a. Seleksi 2 pertanyaan, b. Jenis dan jumlah koleksi 13 pertanyaan, c. Pengorganisasian bahan perpustakaan 3 pertanyaan, d. Kelengkapan fisik 1 pertanyaan. (3) Perawatan koleksi perpustakaan terdiri dari 2 komponen yaitu; a. Pencacahan dan penyiangan 2 pertanyaan, b. Pelestarian 3 pertanyaan.
2. Sarana dan prasarana terdiri dari 7 komponen dan 33 pertanyaan yaitu: (1) Gedung/ruang yang terdiri dari 6 pertanyaan, (2) Kondisi perpustakaan 17 pertanyaan, (3) Peralatan multimedia 3 pertanyaan, (4) Perlengkapan berbasisi TIK 2 pertanyaan, (5) Jaringan automasi 3 pertanyaan, (6) Sarana Keamanan 1 pertanyaan, (7) Fasilitas Umum 1 pertanyaan.

3. Aspek Layanan terdiri dari 6 komponen dan 19 pertanyaan yaitu: (1) Jenis pelayanan 2 pertanyaan, (2) Jam buka layanan 1 pertanyaan, (3) Sarana akses/penelusuran 5 pertanyaan, (4) Keanggotaan 2 pertanyaan, (5) Jumlah pengunjung dan buku yang dipinjam 3 pertanyaan, (6) promosi 3 pertanyaan, (7) Literasi Informasi 3 pertanyaan.

4. Aspek tenaga perpustakaan terdiri dari 2 komponen dan 9 pertanyaan yaitu; (1) Kepala perpustakaan terdiri 3 pertanyaan, (2) Tenaga perpustakaan 3 pertanyaan, (3) Peningkatan kompetensi tenaga perpustakaan 2 pertanyaan, (4) Keikutsertaan dalam organisasi profesi 1 pertanyaan.

5. Aspek penyelenggaraan dan pengelolaan perpustakaan terdiri dari 5 komponen dan 12 pertanyaan yaitu; (1) Aspek Penyelenggaraan 2 pertanyaan, (2). Struktur organisasi 2 pertanyaan, (3) Program dan perencanaan 2 pertanyaan, (4) Anggaran 4 pertanyaan, (5) kerjasama 2 pertanyaan.

6. Aspek Penguat terdiri dari 6 kompenen dan 6 pertanyaan yaitu; (1) Inovasi dan kreativitas 1 pertanyaan, (2) Keunikan 1 pertanyaan, (3) Prestasi 1 pertanyaan, (4) Komitmen pimpinan 1 pertanyaan (5) komponen lain-lainya 2 pertanyaan. 


\section{Info Bibliotheca}

Published by Program Studi Perpustakaan dan Ilmu Informasi

Diklat penting dilakukan penguatan kompetensi sumber daya manusia pengelola perpustakaan sekolah dan madrasah, melalui pelatihan pengelolaan perpustakaan sekolah dan madrasah peserta pelatihan diharapkan dapat meningkatkan kemampuan khususnya dalam melaksanakan tugasnya sebagai tenaga perpustakaan sekolah (Laksmi Dewi dan Asep Dudi Suhardini, 2014) demi terwujudnya perpustakaan yang baik dan nyaman bagi siswa dan pengunjung pemustaka lainnya serta terwujudnya pengelola perpustakaan yang profesional dan kompeten di bidangnya.

Kegiatan diklat ini dilaksanakan selama 4 hari dari tanggal 8 sd. 11 November 2018 di aula Kemenag Kota Padang Aula Saili Tamin Jalan Duku no.5 Kel. Ujung Gurun Padang. Hari pertama dan kedua (tanggal 8 sd. 9 November 2018) dilaksanakan diklat tingkat dasar. Hari ke tiga dan ke empat (tanggal 10 sd. 11 November 2018) dilaksanakan diklat tingkat lanjutan. Dari setiap tahap diklat yang dilakukan ada ujian pre test dan post test yang bertujuan untuk menguji sejauh mana kemampuan dan wawasan dari setiap peserta tentang pemahaman mereka yang berkaitan dengan dunia perpustakaan khususnya di lingkungan tempat mereka bekerja.

Dari hasil ujian pre test dan post test yang diperoleh peserta diklat dapat dikategorikan dalam 3 kategori

1. Kategori nilai rendah $=\mathrm{x}<50$

2. Kategori nilai sedang $=50<\mathrm{x}$ $<75$
3. Kategori nilai tinggi $=\mathrm{x}>75$

Maksudnya dari 3 jenis kategori tersebut dijelaskan bahwa dari 32 peserta yang hadir yang memperoleh nilai dibawah 50 adalah termasuk kategori nilai rendah yang diperoleh peserta, sementara untuk nilai 50 sampai 70 adalah kategori nilai sedang yang diperoleh peserta, untuk kategori nilai tinggi adalah peserta yang memperoleh nilai 75 keatas. Berikut dilampirkan jumlah peserta yang memperoleh nilai dari masing-masing kategori tersebut.

Tabel 2. Total masing-masing kategori nilai dari peserta Diklat Tingkat Dasar

\begin{tabular}{|c|c|c|}
\hline Kriteria & Pre Test & Post Test \\
\hline Rendah & 3 & 2 \\
\hline Sedang & 17 & 21 \\
\hline Tinggi & 12 & 9 \\
\hline
\end{tabular}

Tabel 3. Total masing-masing kategori nilai dari peserta Diklat Tingkat Lanjutan

\begin{tabular}{|c|c|c|}
\hline Kriteria & Pre Test & Post Test \\
\hline Rendah & 2 & 2 \\
\hline Sedang & 29 & 23 \\
\hline Tinggi & 1 & 7 \\
\hline
\end{tabular}

Dari hasil nilai pre test dan post test peserta rata-rata memperoleh nilai dengan kategori sedang, semoga dengan adanya pelatihan ini akan terus menambah wawasan skill dan kemampuan peserta dalam mengelola perpustakaan, karena berhasilnya sebuah perpustakaan dalam meningkatkan kwalitas dan kemajuan perpustakaan adalah tergantung sumber daya manusianya dimana sebelumnya sudah disebutkan bahwa SDM merupakan aset dan investasi masa depan yang memegang peranan 
penting dalam menentukan jati diri suatu bangsa dan revolusi industri 4.0 juga akan berhasil dilaksanakan jika sumber daya manusianya nya berkompeten dibidangnya. Oleh karena itu seorang pustakawan harus mampu menyiapkan skill pengetahuan, teknologi, informasi, komunikasi dan sosial. Dan hal ini juga tidak akan berhasil jika seluruh unsur pimpinan tidak bisa bekerjasama dengan baik demi memajukan perpustakaan dalam menghadapi revolusi industri 4.0

\section{PENUTUP}

\section{Simpulan}

1. Sumber daya manusia yang ditugaskan untuk mengelola perpustakaan di banyak lembaga pendidikan, khususnya madrasah, umumnya hampir tidak pernah mendapatkan perhatian serius. Pada umumnya pengelolaan perpustakaan hanya ditangani oleh mereka yang sama sekali tidak mempunyai latar belakang pendidikan dan ketrampilan yang memadai dalam masalah pengelolaan perpustakaan dan juga tidak memahami arti pentingnya fungsi perpustakaan pada sistem pendidikan karena rata-rata yang menjadi kepala perpustakaan dijabat oleh guru bidang studi. Dan yang menjadi tenaga pengelola sehari-hari adalah pegawai honorer yang jarang sekali mendapatkan peatihan dan pendidikan dibidang ilmu perpustakaan.

2. Minimnya akses pustakawan/pengelola perpustakaan sekolah di Kota Padang untuk mengembangkan kompetensinya (pengetahuan, skill dan sikap). Tidak adanya tersedia lembaga maupun organisasi yang melakukan pembinaan kesekolah-sekolah dan madrasah untuk melatih tenaga-tenaga pengelola perpustakaan sekolah tersebut, seperti yang Tim Pengabdian lakukan sekarang ini, mereka berharap adanya minimal setahun sekali kegiatan pelatihan dan pendidikan gratis tentang bagaimana cara mengembangkan perpustakaan yang profesional dan berkwalitas apalagi nanti akan digalakkan perpustakaan menuju revolusi industri 4.0, sementara untuk saat sekarang saja rata-rata perpustakaan belum beralih ke revolusi industri 2.0. akankah revolusi industi 4.0 akan tercapai dengan melihat kondisi saat sekarang ini.

\section{Saran}

Untuk menciptakan keadaan yang kondusif bagi perpustakaan dan pengelola perpustakaan untuk mampu berperan sebagai unsur penunjang pendidikan, maka diperlukan kebijakan Dinas Pendidikan Nasional, Kementrian Agama, Dinas Kearsipan dan Perpustakaan Propinsi Sumatera Barat dan pihak sekolah atau madrasah yang bersangkutan. Penyelenggaraan berbagai workshop dan pelatihan adalah diantara upaya untuk meningkatkan kualitas tenaga pengelola perpustakaan, sehingga menjadikan mereka menjadi tenaga perpustakaan yang profesional, handal, dan memiliki kompetensi memadai untuk mengelola perpustakaan menjadi lebih baik. Demi terwujudnya perpustakaan ideal sesuai dengan tuntutan zaman apalagi menghadapi tantangan revolusi industri 4.0. 
Published by Program Studi Perpustakaan dan IImu Informasi FBS Universitas Negeri Padang, Indonesia

\section{UCAPAN TERIMA KASIH}

Kegiatan pengabdian ini terselenggara berkat kerja sama antara Lembaga Penelitian dan Pengabdian Masyarakat (LPPM) UIN Imam Bonjol Padang dengan Dirjen Diktis Kementerian Agama RI yang telah memberikan support dana bantuan demi terlaksananya kegiatan diklat tersebut.

\section{DAFTAR PUSTAKA}

Abrori, A. (2018). Improving Reading Literacy Strategy through Seven Programs of Reading Interest containing Da'wah Message. ATTARBIYAH: Journal of Islamic Culture and Education, 3(2), 205225.

Adhiarya, K., Setyadi, A., \& Suwarno, W. (2013). Kajian sikap pustakawan dalam meningkatkan kualitas layanan di perpustakaan fakultas teknologi informasi dan komunikasi Universitas Semarang. Jurnal Ilmu Perpustakaan, 2(1), 77-88.

Aguswara, W. W. (2018). PENGUATAN BUDAYA GERAKAN LITERASI MEMBACA DAN MENULIS BAGI SISWA KELAS AWAL DI SEKOLAH DASAR. Sepeda (Seminar Pendidikan Dasar) PGSD FKIP Unpas, 1(1), 1-10.

AUDINA, W. (2019). Meningkatkan Budaya Literasi Untuk Mutu Pendidikan Yang Berkualitas Dan Peradaban Yang Unggul.

Azmar, N. J. (2018). Masa depan perpustakaan seiring perkembangan revolusi industri 4.0: Mengevaluasi peranan pustakawan. IQRA: Jurnal Ilmu
Perpustakaan Dan Informasi (eJournal), 12(1), 33-41.

Desriyeni, D. (2018). PENGELOLAAN PERPUSTAKAAN SEKOLAH SMAN 1 BUKIT SUNDI DAN SMAN 1 LEMBANG JAYA KABUPATEN SOLOK. Dinamisia: Jurnal Pengabdian Kepada Masyarakat, 2(1), 14-21.

Djafar, H., Warouw, D. M., \& Lesnussa, R. (2018). Manfaat Kode Etik Staf Perpustakaan Dalam Melayani Pengunjung Di Dinas Perpustakaan Dan Kearsipan Kota Tidore. ACTA DIURNA KOMUNIKASI, 7(4).

Hasanah, U. (2019). Pengembangan Pembelajaran Literasi Membaca untuk Meningkatkan Daya Baca Siswa. Media Pustakawan, 26(2), 129-139.

Hayati, R. (2019). PENGEMBANGAN LEMBAR KERJA SISWA (LKS) UNTUK MENINGKATKAN KEGIATAN BERLITERASI SISWA KELAS IV SD DI KECAMATAN HAMPARANPERAK [PhD Thesis]. UNIMED.

Irawan, A. (2019). PENGARUH MODEL PEMBELAJARAN DAN MINAT BELAJAR TERHADAP HASIL BELAJAR IPS DI KELAS VII SMP ALAZHAR MEDAN [PhD Thesis]. UNIMED.

Kristiawan, M. (2016). Telaah Revolusi Mental dan Pendidikan Karakter dalam Pembentukkan Sumber Daya Manusia Indonesia Yang Pandai dan Berakhlak Mulia. Ta'dib, 18(1), 13-25.

Nurhayati, M. (2012). Analisis Integrasi Pasar Modal Kawasan ASEAN dalam Rangka Menuju Masyarakat Ekonomi ASEAN. SEMINAR 
NASIONAL DAN CALL FOR PAPERS.

Nuswantara, K. (2018). PHOTO-VOICE: OPTIMALISASI PERAN TAMAN BACA MASYARAKAT (TBM) SEBAGAI SARANA PENGUATAN LITERASI DANPENGEMBANGAN ABORATORIUM PEMBELAJARAN SEPANJANG HAYAT. IPTEK Journal of Proceedings Series, 5, 90-97.

Prianto, A. (2015). Urgensi Penguatan Budaya Wirausaha Untuk Meningkatkan Daya Saing Indonesia di Era MEA. Jurnal Economia, 11(1), 89-106.

Purnomo, P. (2004). Pembinaan dan pengembangan SDM perpustakaan pada lembaga pendidikan. AL-MAKTABAH, 6(1).

RE, S. (2003). Manajemen sumber Daya manusia.

Rosmaya, E. (2018). MENUMBUHKAN MINAT BACA ANAK MENGUNAKAN MEDIA BIG BOOK UNTUK MENCIPTAKAN BUDAYA LITERASI DI SD 1 BALAGEDOG, KECAMATAN SINDANGWANGI, KABUPATEN MAJALENGKA. Caruban: Jurnal Ilmiah Ilmu Pendidikan Dasar, 1(1), 42-47.

Santoso, H. (2007). Promosi sebagai media pemberdayaan perpustakaan sekolah. Jurnal Perpustakaan Sekolah, 1(1), 1-8.

Setianda, V., \& Andadari, R. K. (2015). Menimbang Daya Saing Pariwisata Indonesia (Dibandingkan Singapura, Malaysia, Dan Thailand). Jurnal Manajeman Bisnis Indonesia, 2(3).

Sudarsono, B. (2017). PERPUSTAKAAN SEKOLAH Suatu Keniscayaan dalam Penyelenggaraan
Pendidikan Formal. Acarya Pustaka, 1(2).

Sumbangsih, N., \& Nelisa, M. (2013). Pengaruh pemberian insentif terhadap motivasi kerja pustakawan di perpustakaan Universitas Bung Hatta Padang. Ilmu Informasi Perpustakaan Dan Kearsipan, 2(1), 178-185.

Suragangga, I. M. N. (2017). Mendidik lewat literasi untuk pendidikan berkualitas. Jurnal Penjaminan Mutu, 3(2), 154-163.

Vanbela, V. T., Fuad, N., \& Marini, A. (2018). Evaluasi program gerakan literasi sekolah di SDN Rorotan 05 Kota Jakarta Utara. Indonesian Journal of Primary Education, 2(2), 1-13.

Zati, V. D. A. (2018). Upaya untuk meningkatkan minat literasi anak usia dini. JURNAL BUNGA RAMPAI USIA EMAS, 4(1), 18-21. 